\title{
The Metabolism of Aromatic Compounds Related to Lignin by some Hyphomycetes and Yeast-like Fungi of Soil
}

\author{
By MOIRA E. K. HENDERSON \\ Department of Microbiology, Macaulay Institute for Soil Research, \\ Craigiebuckler, Aberdeen
}

(Received 8 March 1961)

\begin{abstract}
SUMMARY
The metabolism of various lignin-related aromatic compounds by several soil Hyphomycetes and yeast-like fungi was investigated. Adaptation studies with whole organisms and cell-free extracts confirmed previously proposed metabolic pathways (Henderson \& Farmer, 1955; Henderson, 1960). It was shown that protocatechuic acid is an intermediate in the metabolism of vanillin and ferulic acid. Protocatechuic acid oxidase activity of cell-free extracts of Pullularia pullulans was found to be stimulated by ferrous ions and to depend on $-\mathrm{SH}$ groups.
\end{abstract}

\section{INTRODUCTION}

The studies reported in the previous paper (Henderson, 1961) were extended by investigation of the metabolism of several lignin-related aromatic compounds by yeast-like fungi of soil. Techniques previously employed with other soil microfungi for studying oxygen uptakes (Henderson, 1956) and for the isolation of intermediate products of metabolism (Henderson, 1957) were used. Cell-free extracts of Pullularia pullulans were found to possess protocatechuic acid oxidase activity, a property which proved to be very useful for indicating the adaptation to protocatechuic acid of organisms which had been exposed to several aromatic compounds. Thus these compounds could be associated in metabolic pathways which finally passed through protocatechuic acid.

\section{METHODS}

Organisms. These were isolated by a soil-enrichment technique (Henderson, 1961). They were Pullularia pullans, Margarinomyces heteromorpha, Margarinomyces mutabilis (2 isolates), Phialophora aurantiaca, Geotrichum candidum, Fusarium sp. and unidentified isolates no. 8 and 10.

Production of organisms. The fungi were grown on the basal mineral salts medium previously used (Henderson, 1961), to which were added glucose, Difco yeast extract and aromatic compounds as required. For metabolic experiments in the Warburg apparatus and for the large-scale metabolic experiments the growth medium contained $1 \%(\mathrm{w} / \mathrm{v})$ glucose and $0.5 \%(\mathrm{w} / \mathrm{v})$ yeast extract. The medium was dispensed in $40 \mathrm{ml}$. lots in $250 \mathrm{ml}$. conical flasks; incubation was for 3 days at $27^{\circ}$ on a shaking machine (Webley \& Duff, 1955). The growth was then harvested and washed three times with distilled water. When the organisms were to be adapted to different substrates the harvesting and washing were carried out aseptically, and the washed 
organisms transferred to $250 \mathrm{ml}$. conical flasks containing $50 \mathrm{ml} .0 .067 \mathrm{M}$-phosphate buffer (Clark, 1928) at $\mathrm{pH} 5 \cdot 2$, and substrate at $\mathbf{0 . 0 0 1} \mathrm{M}$. Control organisms were transferred to buffer only. After incubation overnight on the shaking machine the organisms were again harvested and washed.

In the production and adaptation of cells of Pullularia pullulans for preparation of crude cell-free extracts organisms were obtained from $160 \mathrm{ml}$. lots of medium containing $2 \%(\mathrm{w} / \mathrm{v})$ glucose $\pm 0.001 \mathrm{~m}$-aromatic compounds. The media were dispensed in 1 l. culture flasks (Jobling Cat. no. 1410). Since the fungus would not grow in the presence of catechol or 0 -hydroxybenzoic acid, when these substances were being investigated it was grown on the basal mineral salts medium $+2 \%(\mathrm{w} / \mathrm{v})$ glucose, and the organisms were adapted by transferring them aseptically to phosphate buffer $(\mathrm{pH} \mathrm{5.2)}+0.001 \mathrm{M}$ solutions of these compounds and then incubating overnight. Control organisms were transferred to buffer only.

Manometry. Initially the respiration of Pullularia pullulans and Margarinomyces mutabilis in the presence of vanillin was tested over a range from $\mathrm{pH} 4$ to $\mathrm{pH} 8$ (McIlvaine's buffer). Since neither species was sensitive over this $\mathrm{pH}$ range it was decided to use $0.067 \mathrm{M}$-phosphate buffer ( $\mathrm{pH} \mathrm{5.2)}$ ) as in previous experiments with soil fungi (Henderson, 1956). In experiments with whole organisms $1.0 \mathrm{ml}$. of suspension (containing about $7 \mathrm{mg}$. dry wt. organism $/ \mathrm{ml}$. and $\mathbf{0 . 5} \mathrm{ml}$. buffer were added to the main compartment of each Warburg flask, $0.2 \mathrm{ml} .5 \%$ (w/v) KOH to the centre cup and $\mathbf{0 . 5} \mathrm{ml}$. of $0.01 \mathrm{~m}$ solutions of substrates (except ferulic acid which was $0.003 \mathrm{~m}$ ) to the side-arm. Acid substrates were neutralized with sodium hydroxide. Experiments were conducted at $30^{\circ}$ in air. Readings were taken at $30 \mathrm{~min}$. intervals for $3 \frac{1}{2} \mathrm{hr}$., substrates being tipped in from the side-arms after $30 \mathrm{~min}$. In experiments with cell-free extracts $0.5 \mathrm{ml}$. of the extracts and $1.0 \mathrm{ml}$. of 0.067 M-phosphate buffer ( $\mathrm{pH} 7$ ) were added to the main compartment and $0.02 \mathrm{M}$ solutions of substrates were used. Substrates were tipped from the side-arms at $0 \mathrm{hr}$. and experiments were run for $4 \mathrm{hr}$. before carrying out $\beta$-ketoadipic acid estimations. Otherwise conditions were the same as those for experiments with whole organisms.

Large-scale metabolic experiments. Suspensions containing about $11 \mathrm{mg}$. dry wt. Pullularia pullulans $/ \mathrm{ml}$., $10 \mathrm{mg}$. dry wt. Margarinomyces heteromorpha/ml. and $6 \mathrm{mg}$. dry wt. M. mutabilis $/ \mathrm{ml}$. were used. Three $\mathrm{ml}$. of suspension were added to $25 \mathrm{ml}$. 0.01 $\mathrm{M}$ substrate solution in $100 \mathrm{ml}$. conical flasks (except in the case of ferulic acid when $25 \mathrm{ml}$. $0.003 \mathrm{M}$ substrate solution was used). The aldehydes were sterilized by filtration through sintered glass and the acids by autoclaving at $120^{\circ}$ for $20 \mathrm{~min}$. at $\mathrm{pH} \mathrm{6 \cdot 5}$. After addition of the suspensions the flasks were incubated on the shaking machine and one flask of each substrate was removed after 5 and $22 \mathrm{hr}$. The growth was removed by centrifugation, the supernatant fluid acidified and extracted 3 times with $10 \mathrm{ml}$. ether. The ether was removed by evaporation and the extracts were dissolved in a few drops of absolute ethanol. Samples were applied to Whatman no. 1 filter papers which were developed with $n$-butanol+ammonia (sp.gr. $0 \cdot 880)+$ water $\left(80+5+15\right.$ vol.) for $16 \mathrm{hr}$. at $21^{\circ}$ by the descending method. They were sprayed with diazotized sulphanilic acid (Bray, Thorpe \& White, 1950).

Cell-free extracts. Crude extracts of organisms were prepared according to the method of McIlwain (1948). The organisms were harvested, washed three times and ground in a pestle and mortar with three times their wet weight of alumina ( $\mathbf{H}$ fine Aloxite, The Carborundum Company Ltd., Manchester, 17). For this purpose 
approximately $2 \mathrm{~g}$. wet wt. organism were used. The crushed organisms were extracted with $3 \mathrm{ml}$. of $0 \cdot 067 \mathrm{~m}$-phosphate buffer $(\mathrm{pH} 7)$. The crude extract was freed from alumina by centrifugation at $1600 \mathrm{~g}$ for $10 \mathrm{~min}$. After the crude extract had been centrifuged at $20,000 \mathrm{~g}$ for $30 \mathrm{~min}$. precipitation with $\left(\mathrm{NH}_{4}\right)_{2} \mathrm{SO}_{4}$ was sometimes carried out according to Dagley \& Patel (1957). The precipitates obtained were separated by centrifugation at $20,000 \mathrm{~g}$ for $30 \mathrm{~min}$. The supernatant fluids were removed and the precipitates dissolved in a volume of $0.02 \mathrm{M}$-phosphate buffer ( $\mathrm{pH} 7$ ) equal to the volumes of crude extract from which they were prepared.

$\beta$-Ketoadipic acid estimation. The presence of $\beta$-ketoadipic acid was detected by the Rothera test (Rothera, 1908). The amount of acid present was estimated by decarboxylation with 4 -aminoantipyrine and measuring the carbon dioxide evolved (Sistrom \& Stanier, 1953).

\section{RESULTS}

Oxygen uptake by fungi in the presence of aromatic substrates

In experiment 1 (Table 1) oxygen uptakes in the presence of $p$-hydroxybenzaldehyde, ferulic acid, syringaldehyde and vanillin were measured. All species metabolized these substrates to some extent, but there was considerable variation

Table 1. Oxygen uptake by fungi in presence of aromatic compounds

Added to each flask were: $1.0 \mathrm{ml}$. cell suspension (equiv. about $7 \mathrm{mg} . / \mathrm{ml}$. dry wt.) $+0.5 \mathrm{ml}$. phosphate buffer ( $\mathrm{pH} \mathrm{5.2}$ ) in the main compartment; $0.2 \mathrm{ml} .5 \%(\mathrm{w} / \mathrm{v}) \mathrm{KOH}$ in centre cup; $0.5 \mathrm{ml} .0 .01 \mathrm{M}$ solutions of substrates (except ferulic acid which was $3 \times$ $0.001 \mathrm{M}$ ) or $0.5 \mathrm{ml}$. water in side-arm. In Expt. 2 the cells were starved by shaking overnight in phosphate buffer ( $\mathrm{pH}$ 5.2). The figures refer to oxygen uptake over the $3 \mathrm{hr}$. period following the addition of substrates.

Expt. 1.

Substrate

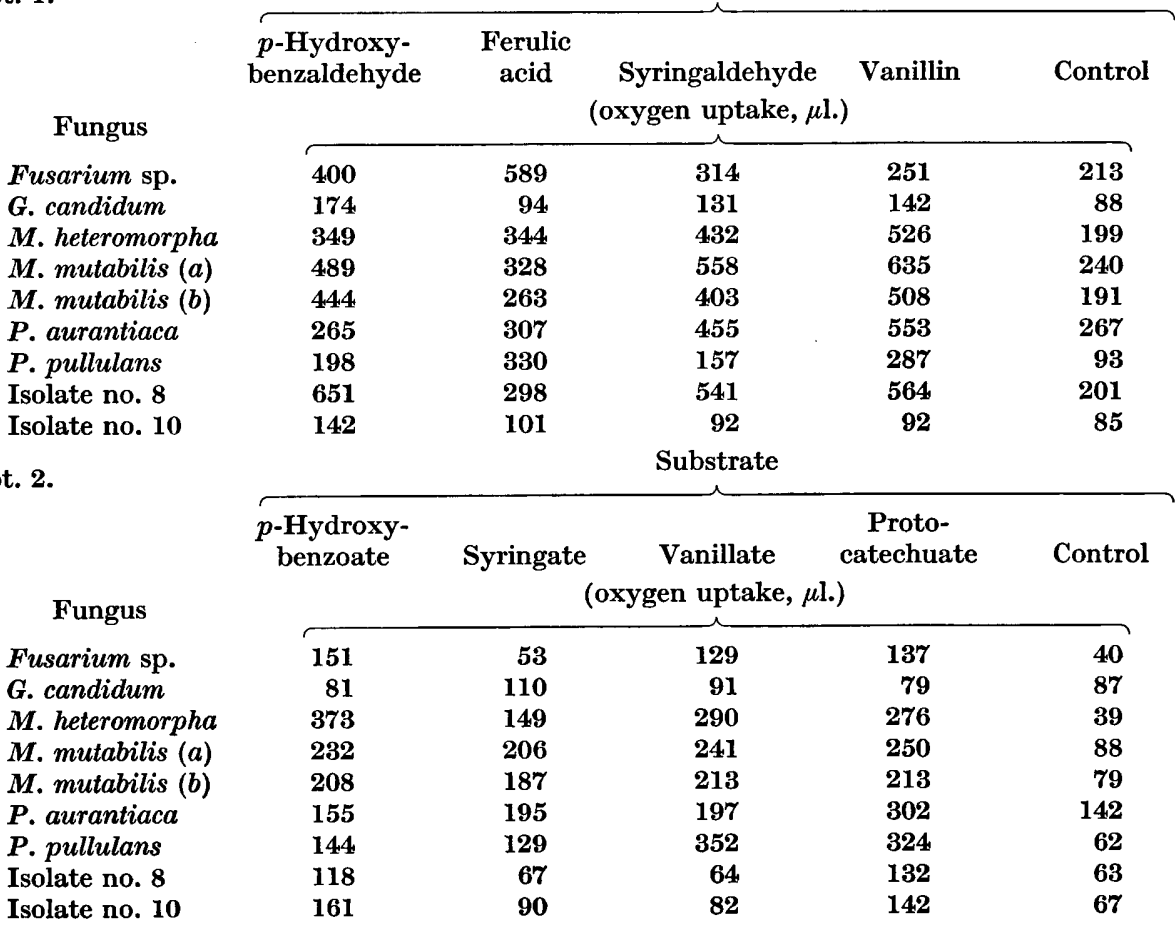


in the oxygen uptakes by different isolates on different substrates. These substrates were metabolized without any lag period. In Expt. 2 (Table 1) oxygen uptakes in the presence of sodium $p$-hydroxybenzoate, syringate, vanillate and protocatechuate were recorded. Since the rates of oxygen uptake with this group of substrates were considerably slower than with the first group, overnight starvation of the organisms in buffer was necessary to decrease the endogenous respiration. This made the differences in oxygen uptakes between the control and experimental flasksmore distinct. In contrast to Expt. 1 there were lag periods for all these substrates before the oxygen uptakes reached their maximum rate, as found previously for other soil fungi (Henderson, 1956). The lag period with Pullularia pullulans on protocatechuic acid was eliminated by previous incubation with vanillin, vanillic acid, $p$-hydroxybenzaldehyde or $p$-hydroxybenzoic acid (Fig. 1, $a, b$ ). Incubation with syringic acid did not appear to lead to adaptation to protocatechuic acid. Previous incubation with ferulic acid eliminated the lag period with vanillic acid.
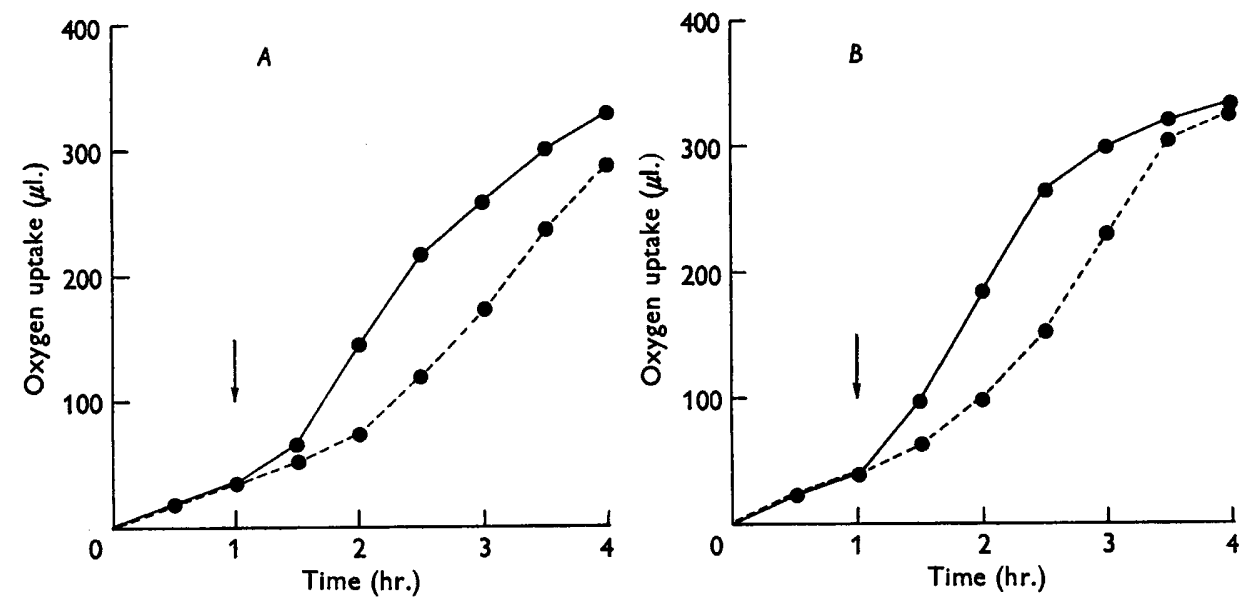

Fig. $1, A, B$. Oxygen uptake by Pullularia pullulans in the presence of protocatechuic acid. Added to each flask were : $1.0 \mathrm{ml}$. organism suspension (equiv. about $7 \mathrm{mg}$. dry wt.) $\mathrm{ml}).+0.5 \mathrm{ml}$. phosphate buffer (pH 5.2) in main compartment; $0.2 \mathrm{ml} .5 \%(\mathrm{w} / \mathrm{v}) \mathrm{KOH}$ in centre cup; $0.5 \mathrm{ml} .0 .01 \mathrm{M}$ solution of protocatechuic acid in side arm. $-=$ adapted cells ; --- = non-adapted cells. $A$ : cells adapted to vanillin; $B$ : cells adapted to $p$-hydroxybenzaldehyde. Protocatechuic acid added where indicated by arrow.

\section{Intermediate products of metabolism detected in large-scale metabolic experiments}

All of the aromatic compounds tested were attacked by the fungi and some were so rapidly metabolized that no trace of them could be found when incubation proceeded beyond 2 days. The principal intermediate products detected (see Table 2) included those found previously (Henderson \& Farmer, 1955; Henderson, 1957): $p$-hydroxybenzoic acid from $p$-hydroxybenzaldehyde, vanillic acid from vanillin and ferulic acid, syringic acid from syringaldehyde, the hydroxybenzoic acids from the corresponding mono-methoxybenzoic acids, protocatechuic acid from $p$-hydroxybenzoic acid, $p$-hydroxybenzoic and protocatechuic acids from benzoic acid and vanillic acid from 3:4-dimethoxybenzoic acid. No intermediates 


\section{Table 2. Principal intermediate products of metabolism of aromatic compounds detected by paper chromatography}

Suspensions of organisms were added to $25 \mathrm{ml}$. of $0.01 \mathrm{M}$ solutions of the substrates and incubated for 5 or $22 \mathrm{hr}$. The cell material was removed and the supernatant fluids extracted with ether. The extracts were examined by paper chromatography. Papers were developed with $n$-butanol + ammonia (sp.gr. 0.880) + water $(80+5+15)$ for 16 hr. at $21^{\circ}$, by the descending method. They were sprayed with diazotized sulphanilic acid. $\boldsymbol{R}_{F}$ values were calculated from leading edge of spots.

\begin{tabular}{|c|c|c|c|c|c|c|}
\hline \multirow[b]{2}{*}{ Substrate } & \multicolumn{6}{|c|}{ Organism } \\
\hline & $\begin{array}{l}P \cdot \text { pullulans, } \\
\text { product or colour }\end{array}$ & $\boldsymbol{R}_{\boldsymbol{F}}$ & $\begin{array}{l}M . \text { heteromorpha, } \\
\text { product or colour }\end{array}$ & $\boldsymbol{R}_{\boldsymbol{F}}$ & $\begin{array}{l}\text { M. mutabilis, } \\
\text { product or colour }\end{array}$ & $\boldsymbol{R}_{F}$ \\
\hline Benzoic acid & $\begin{array}{l}p \text {-Hydroxybenzoic } \\
\text { acid }\end{array}$ & $0 \cdot 267$ & $\begin{array}{l}p \text {-Hydroxybenzoic } \\
\text { acid }\end{array}$ & $0 \cdot 262$ & $\begin{array}{l}p \text {-Hydroxybenzoic } \\
\text { acid }\end{array}$ & $0 \cdot 283$ \\
\hline & $\begin{array}{l}\text { Protocatechuic } \\
\text { acid }\end{array}$ & 0.057 & & & $\begin{array}{l}\text { Protocatechuic } \\
\text { acid }\end{array}$ & 0.058 \\
\hline Ferulic acid & Vanillic acid & $0 \cdot 133$ & Vanillic acid & $0 \cdot 125$ & Vanillic acid & $0 \cdot 117$ \\
\hline $\begin{array}{l}p \text {-Hydroxy- } \\
\text { benzaldehyde }\end{array}$ & $\begin{array}{l}p \text {-Hydroxybenzoic } \\
\text { acid }\end{array}$ & $0 \cdot 141$ & $\begin{array}{l}p \text {-Hydroxybenzoic } \\
\text { acid }\end{array}$ & $0 \cdot 131$ & $\begin{array}{l}p \cdot \text {-Hydroxybenzoic } \\
\text { acid }\end{array}$ & $0 \cdot 175$ \\
\hline & ? Yellow & 0.885 & & & ? Yellow & $0 \cdot 836$ \\
\hline & ? Yellow & 0.784 & & & & \\
\hline $\begin{array}{l}o-H y d r o x y- \\
\text { benzoic acid }\end{array}$ & ? Yellow & $0 \cdot 183$ & ? Yellow & $0 \cdot 152$ & $\begin{array}{l}\text { Gentisic acid } \\
\text { ? Yellow }\end{array}$ & $\begin{array}{l}0 \cdot 239 \\
0 \cdot 162\end{array}$ \\
\hline $\begin{array}{l}m \text {-Hydroxy- } \\
\text { benzoic acid }\end{array}$ & 一 & & $\begin{array}{l}\text { Protocatechuic } \\
\text { acid }\end{array}$ & $0 \cdot 042$ & - & \\
\hline $\begin{array}{l}p \text {-Hydroxy- } \\
\text { benzoic acid }\end{array}$ & $\begin{array}{l}\text { Protocatechuic } \\
\text { acid }\end{array}$ & $0 \cdot 046$ & $\begin{array}{l}\text { Protocatechuic } \\
\text { acid }\end{array}$ & 0.062 & $\begin{array}{l}\text { Protocatechuic } \\
\text { acid }\end{array}$ & 0.025 \\
\hline $\begin{array}{l}\text { o-Methoxy- } \\
\text { benzoic acid }\end{array}$ & $\begin{array}{l}o \text {-Hydroxybenzoic } \\
\text { acid }\end{array}$ & 0.584 & $\begin{array}{l}o \text {-Hydroxybenzoic } \\
\text { acid }\end{array}$ & $0 \cdot 474$ & $\begin{array}{l}\text { o-Hydroxybenzoic } \\
\text { acid }\end{array}$ & $0 \cdot 492$ \\
\hline $\begin{array}{l}m \text {-Methoxy- } \\
\text { benzoic acid }\end{array}$ & $\begin{array}{l}m \text {-Hydroxybenzoic } \\
\text { acid }\end{array}$ & $0 \cdot 223$ & - & & $\begin{array}{l}m \text {-Hydroxy- } \\
\text { benzoic acid }\end{array}$ & $0 \cdot 283$ \\
\hline $\begin{array}{l}p \text {-Methoxy- } \\
\text { benzoic acid }\end{array}$ & $\begin{array}{l}p \text {-Hydroxybenzoic } \\
\text { acid }\end{array}$ & $0 \cdot 179$ & $\begin{array}{l}p \text {-Hydroxybenzoic } \\
\text { acid }\end{array}$ & $0 \cdot 140$ & $\begin{array}{l}p \text {-Hydroxybenzoic } \\
\text { acid }\end{array}$ & $0 \cdot 173$ \\
\hline $\begin{array}{l}\text { 3:4-Dimeth- } \\
\text { oxybenzoic acid }\end{array}$ & Vanillic acid & $0 \cdot 122$ & - & & Vanillic acid & $0 \cdot 126$ \\
\hline $\begin{array}{l}\text { 24-Dimeth- } \\
\text { oxybenzoic acid }\end{array}$ & d Orange-Yellow & $0 \cdot 107$ & $\begin{array}{l}\text { ? Yellow } \\
\text { ? Orange }\end{array}$ & $\begin{array}{l}0 \cdot 272 \\
0 \cdot 129\end{array}$ & $\begin{array}{l}\text { ? Orange } \\
\text { ? Pink-Orange }\end{array}$ & $\begin{array}{l}0 \cdot 320 \\
0 \cdot 113\end{array}$ \\
\hline $\begin{array}{l}\text { Syringalde- } \\
\text { hyde }\end{array}$ & $\begin{array}{l}\text { Syringic acid } \\
\text { ? Red }\end{array}$ & $\begin{array}{l}0 \cdot 104 \\
0 \cdot 827\end{array}$ & & & & \\
\hline Vanillin & $\begin{array}{l}\text { Vanillic acid } \\
\text { Vanillyl alcohol }\end{array}$ & $\begin{array}{l}0 \cdot 129 \\
0 \cdot 797\end{array}$ & Vanillic acid & $0 \cdot 143$ & $\begin{array}{l}\text { Vanillic acid } \\
\text { ? Orange }\end{array}$ & $\begin{array}{l}0 \cdot 179 \\
0 \cdot 774\end{array}$ \\
\hline
\end{tabular}

Colours. Hydroxybenzoic acids: yellow; protocatechuic acid: pink-white; vanillyl groups: orange; genitisic acid : grey-white; syringic acid : red. $-=$ No spots obtained.

from 2:4-dimethoxybenzoic acid were identified. Gentisic acid was formed by Margarinomyces mutabilis from $o$-hydroxybenzoic acid. It was identified as follows. A solution of $o$-hydroxybenzoic acid was incubated in the presence of $\boldsymbol{M}$. mutabilis for 2 days, the organisms removed and the supernatant fluids acidified and extracted with ether. The extract, after application to paper chromatograms, was developed with $n$-propanol + ammonia (sp.gr. $0 \cdot 880)+$ water $(80+5+15$ vol.) and sprayed with diazotized sulphanilic acid. Pure gentisic acid was run as a standard along with the extract. Strips containing standard spots were cut from each side of the paper and the position of gentisic acid in them was located by spraying with diazotized sulphanilic acid. Strips from the centre of the paper, one containing the 
extract and the other gentisic acid, were cut out and the areas in them, corresponding to the location of gentisic acid in the test strips, were removed and eluted with 2.5 ml. 0.067 M-phosphate buffer ( $\mathrm{pH}$ 7). The solutions obtained were examined by ultraviolet spectrometry and were found to have corresponding maxima at $328 \mathrm{~m} \mu$ in acid solution, 317 and $259 \mathrm{~m} \mu$ in alkaline solution and $320 \mathrm{~m} \mu$ in neutral solution, confirming that gentisic acid was present in the extract from the experimental solution.

A number of spots of high $\boldsymbol{R}_{F}$ values which had not been obtained previously were noted. These included vanillyl alcohol which was identified in an extract obtained after incubating a solution of vanillin in the presence of a suspension of Pullularia pullulans for 2 days. After removal of the organisms the supernatant fluid was extracted with ether without previous acidification. The extract yielded a large orange spot of $\boldsymbol{R}_{F} \mathbf{0 . 8 1 2}$ and a faint orange spot of $\boldsymbol{R}_{F} \mathbf{0 . 0 8 5}$ when developed with butanol + ammonia + water $(80+5+15)$ and sprayed with diazotized sulphanilic acid. The former spot corresponded to an unidentified spot obtained in extracts after incubation for $\mathbf{5}$ and $22 \mathrm{hr}$.; the latter spot was vanillic acid. Since the extract contained no residual vanillin it could be used directly for analysis by infrared spectrometry; its spectrum was found to be identical with that of vanillyl alcohol. A spot corresponding to vanillyl alcohol was also obtained on developing the extract from Margarinomyces mutabilis cultures on vanillin. Spots of high $R_{F}$ value from extracts of cultures of the three species on $p$-hydroxybenzaldehyde and of $\boldsymbol{P}$. pullulans on syringaldehyde may also have been the corresponding alcohols, but standards were not available for comparison.

These results indicate that the metabolism was basically similar to that of the filamentous fungi investigated previously, but there was evidence of a strong reducing mechanism in these organisms which led to the formation of alcohols from aldehydes. Vanillyl alcohol was produced even when a stream of air was bubbled through a flask containing Pullularia pullulans and vanillin, but no spot of high $\boldsymbol{R}_{F}$ value was obtained when $p$-hydroxybenzaldehyde was similarly treated.

\section{Protocatechuic acid oxidase activity in cell-free extracts}

Preliminary Warburg experiments showed that cell-free extracts from adapted organisms took up oxygen in the presence of protocatechuic acid and that $\beta$-ketoadipic acid was produced, as indicated by the Rothera test (Rothera, 1908). Extracts from non-adapted organisms showed negligible protocatechuic acid oxidase activity. In subsequent experiments protocatechuic acid oxidase activity was determined by estimating the $\beta$-ketoadipic acid which accumulated after incubation of extracts with protocatechuic acid.

Table 3 shows that protocatechuic acid oxidase activity was well developed in extracts of those organisms which had been exposed to $m$ - and $p$-hydroxybenzoic and vanillic acids, as well as to protocatechuic acid. These results indicate that protocatechuic acid was an intermediate product in the metabolism of these acids. Activity was very low in organisms which had been exposed to syringic acid, signifying that protocatechuic acid was not involved in its metabolism. It can also be seen that exposure to $o$-hydroxybenzoic acid and to catechol did not lead to the adaptation of organisms to protocatechuic acid. However, exposure to these substrates led to adaptation to catechol and cis-cis-muconic acid, while organisms which had been exposed to protocatechuic acid were negative in this respect. 
Table 3. $\beta$-Ketoadipic acid production by crude extracts of Pullularia pullulans from protocatechuic acid, cis-cis-muconic acid and catechol

Before extraction half of the organisms were adapted to various substrates. Added to each flask were: $1.0 \mathrm{ml}$. phosphate buffer $(\mathrm{pH} \mathrm{7})+0.5 \mathrm{ml}$. cell extract in the main compartment; $0.2 \mathrm{ml} .5 \%(\mathrm{w} / \mathrm{v}) \mathrm{KOH}$ in the centre cup; $0.5 \mathrm{ml} .0 .02 \mathrm{M}$ solutions of substrates $\left(10 \mu\right.$ mole) in the side-arm. Experiments were run for $4 \mathrm{hr}$. at $30^{\circ} . \beta$-Ketoadipic acid was estimated by decarboxylation with aminoantipyrine.

Substrate

\begin{tabular}{l}
\multicolumn{1}{c}{ Adapting } \\
substrate \\
Catechol \\
$o$-Hydroxybenzoic acid \\
$m$-Hydroxybenzoic acid \\
$p$-Hydroxybenzoic acid \\
Protocatechuic acid \\
Syringic acid \\
Vanillic acid
\end{tabular}

Adapting

Catechol

$p$-Hydroxybenzoic acid

Syringic acid

Vanillic acid

\begin{tabular}{|c|c|c|c|c|c|}
\hline \multicolumn{6}{|c|}{ Substrate } \\
\hline \multicolumn{2}{|c|}{$\overbrace{}^{\text {Protocatechuic acid }}$} & \multicolumn{2}{|c|}{ cis-cis-Muconic acid } & \multicolumn{2}{|c|}{ Catechol } \\
\hline \multicolumn{6}{|c|}{ Extract: from adapted (A) or non-adapted (NA) organism } \\
\hline $\mathbf{A}$ & NA & $\mathbf{A}$ & NA & $\mathbf{A}$ & $\mathbf{N A}$ \\
\hline \multicolumn{6}{|c|}{$\beta$-ketoadipic acid produced ( $\mu$ mole) } \\
\hline $1 \cdot 4$ & $1 \cdot 4$ & $6 \cdot 5$ & $1 \cdot 8$ & $8 \cdot 8$ & $1 \cdot 4$ \\
\hline $1 \cdot 2$ & 0.9 & $5 \cdot 0$ & 0.9 & $8 \cdot 8$ & $1 \cdot 1$ \\
\hline $6 \cdot 3$ & 1.5 & 一 & 一 & - & 一 \\
\hline $5 \cdot 9$ & 0.7 & - & 一 & - & 一 \\
\hline $8 \cdot 2$ & 0.7 & $0 \cdot 8$ & 0.7 & $0 \cdot 4$ & 0.5 \\
\hline $1 \cdot 9$ & $1 \cdot 3$ & 一 & - & - & 一 \\
\hline $7 \cdot 5$ & $1 \cdot 8$ & - & - & - & - \\
\hline
\end{tabular}

Protocatechuic acid oxidase activity in crude cell-free extracts was partly inhibited by $1 \cdot 4 \times 10^{-4} \mathrm{M}-p$-chloromercuribenzoate $(\mathrm{CMB})$, but activity was retained when glutathione at $1.3 \times 10^{-3} \mathrm{M}$ was present. When the concentration of CMB was increased to $5 \cdot 6 \times 10^{-4} \mathrm{M}$ the enzyme activity was completely inhibited, but was restored by $1.3 \times 10^{-3} \mathrm{M}$ glutathione (see Table 4 ). When crude cell-free extracts were precipitated with $\left(\mathrm{NH}_{4}\right)_{2} \mathrm{SO}_{4}$ and the precipitates dissolved in phosphate buffer according to Dagley \& Patel (1957), the resulting solutions showed considerable protocatechuic acid oxidase activity, which was inhibited by $5 \cdot 6 \times 10^{-4} \mathrm{M}-\mathrm{CMB}$ and

Table 4. Influence of $\mathrm{p}$-chloromercuribenzoate and glutathione on protocatechuic acid oxidase activity in extracts of Pullularia pullulans

Activity was measured by $\beta$-ketoadipic acid production. Organisms were adapted to protocatechuic acid before extraction (crude extract) and precipitation with $\left(\mathrm{NH}_{4}\right)_{2} \mathrm{SO}_{4}$. The precipitate was dissolved in $0.02 \mathrm{M}$-phosphate buffer $\left(\mathrm{pH} 7 ;\left(\mathrm{NH}_{4}\right)_{2} \mathrm{SO}_{4}\right.$ precipitate). Added to each flask were : $1.0 \mathrm{ml}$. phosphate buffer $(\mathrm{pH} 7)+0.5 \mathrm{ml}$. cell extract $+\mathbf{0 . 5} \mathrm{ml}$. $p$-chloromercuribenzoate (CMB), to give a final concentration of $1 \cdot 4 \times 10^{-4} \mathrm{M}$ or $5 \cdot 6 \times$ $10^{-4} \mathrm{M}$, or $0.5 \mathrm{ml}$. water $+0.5 \mathrm{ml}$. glutathione, to give a final concentration of $1.3 \times 10^{-3} \mathrm{M}$ in the main compartment, or $0.5 \mathrm{ml}$. water; $0.2 \mathrm{ml} .5 \%(\mathrm{w} / \mathrm{v}) \mathrm{KOH}$ in the centre cup; $0.5 \mathrm{ml} .0 .02 \mathrm{M}$-protocatechuic acid $(10 \mu \mathrm{mole})$ in the side arm. Experiments were run for $4 \mathrm{hr}$. at $30^{\circ}$. $\beta$-Ketoadipic acid was estimated by decarboxylation with aminoantipyrine.

\begin{tabular}{|c|c|c|c|}
\hline & Cru & act & \\
\hline & Expt. 1 & Expt. 2 & $\begin{array}{l}\left(\mathrm{NH}_{4}\right)_{2} \mathrm{SO}_{4} \\
\text { precipitate }\end{array}$ \\
\hline & $\beta$-ket & acid prod & (umole) \\
\hline (2) & $4 \cdot 5$ & $2 \cdot 3$ & 1.2 \\
\hline CMB $1.4 \times 10^{-4} \mathrm{M}$ & $2 \cdot 2$ & 一 & - \\
\hline CMB $5 \cdot 6 \times 10^{-4} \mathrm{M}$ & - & $\mathbf{0}$ & 0 \\
\hline CMB + Glutathione & $5 \cdot 4$ & $3 \cdot 4$ & $1 \cdot 4$ \\
\hline
\end{tabular}


restored by $1.3 \times 10^{-3} \mathrm{M}$-glutathione (Table 4). Dialysis against $0.022 \mathrm{M}$-phosphate buffer ( $\mathrm{pH} \mathrm{6.9)}$ for $16 \mathrm{hr}$. decreased the activity of crude extracts and was partly restored by $0.001 \mathrm{M}-\mathrm{FeSO}_{4}$. The results were as follows ( $\mu$ mole $\beta$-ketoadipic acid): crude extract, 4.1 ; dialysed extract, $1 \cdot 2$; dialysed extract $+\mathrm{FeSO}_{4}, 2 \cdot 3$; dialysed extract control, 0 . No consistent results were obtained about the influence of glutathione or ferrous ion on the activity of untreated crude extracts, but the activity of solutions of ammonium sulphate precipitates was increased by the presence of $1.6 \times 10^{-3} \mathrm{M}$-glutathione, or $0.001 \mathrm{M}-\mathrm{FeSO}_{4}$ or $\mathrm{FeCl}_{3}$ (see Table 5).

\title{
Table 5. Influence of glutathione and various ions on protocatechuic acid oxidase
} activity in extracts of Pullularia pullulans after treatment with $\left(\mathrm{NH}_{4}\right)_{2} \mathrm{SO}_{4}$

\begin{abstract}
Activity was measured by $\beta$-ketoadipic acid production. Organisms were adapted to protocatechuic acid before extraction which was followed by precipitation with $\left(\mathrm{NH}_{4}\right)_{2} \mathrm{SO}_{4}$ and solution of the precipitates in $0.02 \mathrm{~m}$-phosphate buffer, $(\mathrm{pH} 7)$. Added to each flask were: $1.0 \mathrm{ml}$. phosphate buffer $(\mathrm{pH} 7)+0.5 \mathrm{ml}$. cell extract $+0.5 \mathrm{ml}$. glutathione (to give a final concentration of $1.6 \times 10^{-3} \mathrm{M}$ ) or $0.5 \mathrm{ml} . \mathrm{FeSO}_{4} .7 \mathrm{H}_{2} \mathrm{O}, \mathrm{FeCl}_{3} .6 \mathrm{H}_{2} \mathrm{O}, \mathrm{MnSO}_{4} .5 \mathrm{H}_{2} \mathrm{O}$, or $\mathrm{ZnSO}_{4} .7 \mathrm{H}_{2} \mathrm{O}$ solution (to give a final concentration of $0.001 \mathrm{M}$ ) in the main compartment; $0.2 \mathrm{ml} .5 \%(\mathrm{w} / \mathrm{v}) \mathrm{KOH}$ in the centre cup; $0.5 \mathrm{ml}$. 0.02 M-protocatechuic acid $(10 \mu$ mole $)$ in the side arm. Experiments were run for $4 \mathrm{hr}$. at $30^{\circ} . \beta$-Ketoadipic acid was estimated by decarboxylation with aminoantipyrine.
\end{abstract}

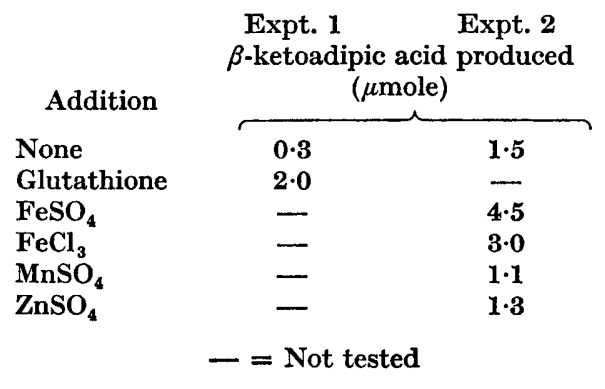

\section{DISCUSSION}

The replacement experiments showed that the soil organisms used in the present work metabolize aromatic compounds in essentially the same way as did those studied previously (Henderson \& Farmer, 1955; Henderson, 1960). The principal difference lay in the reduction of vanillin to vanillyl alcohol and possibly also of $p$-hydroxybenzaldehyde and syringaldehyde to their corresponding alcohols. At the same time, oxidation of the aldehydes with the formation of the corresponding acids was proceeding. This may be compared with the anaerobic dismutation of aldehydes by Acetobacter spp. investigated by Molinari (1929). He found that benzaldehyde, cinnamaldehyde and anisaldehyde were dismuted to their respective acids and alcohols. In contrast Bachman, Dragoon \& John (1960) obtained quantitative conversion of $o$-hydroxybenzoic to the corresponding alcohol by Neurospora crassa, while Polystictus versicolor reduced certain aromatic acids to the corresponding aldehydes and alcohols (Farmer, Henderson \& Russell, 1959). The acids and alcohols found in the present work were intermediate products of metabolism and with time all trace of phenolic compounds disappeared. A further difference from previous findings was the metabolism of $o$-hydroxybenzoic acid through gentisic acid by Margarinomyces mutabilis. Catechol was previously detected as an intermediate 
product of the metabolism of $o$-hydroxybenzoic acid by fungi (Henderson, 1960) and is the most common intermediate in bacterial metabolism. However, Mitoma, Posner, Reitz \& Udenfriend (1956) obtained gentisic acid from $o$-hydroxybenzoic acid when it was subjected to a hydrolysing system found in liver microsomes.

The results from the present experiments showed that protocatechuic acid was an intermediate product in the metabolism of $p$-hydroxybenzoic, $m$-hydroxybenzoic and benzoic acids, while $p$-hydroxybenzoic acid is itself an intermediate in the metabolism of $p$-hydroxybenzaldehyde and $p$-methoxybenzoic acid. Previously the formation of protocatechuic acid, by other fungi, from $m$-hydroxybenzoic acid (Henderson, 1960) and from $p$-hydroxybenzoic acid (Henderson, 1957) was demonstrated; protocatechuic acid is also well known as an intermediate in the metabolism of various aromatic compounds by bacteria. Thus the metabolism of protocatechuic acid itself appears to be a' focal point in the metabolism of aromatic compounds. The principal aim of the present respiration studies with whole organisms and with cell-free extracts was, therefore, directed towards linking the metabolism of various compounds with protocatechuic acid and studying the metabolism of this acid itself.

The morphology of the organisms used here made them very suitable for respiration experiments. In addition, Pullularia pullulans, which was selected for further work with cell-free extracts, lent itself very well to this type of work. Adaptation studies with whole organisms confirmed the postulated pathways of metabolism leading eventually to protocatechuic and $\beta$-ketoadipic acids. Previous incubation with vanillin, vanillic acid, ferulic acid, $p$-hydroxybenzaldehyde or $p$-hydroxybenzoic acid resulted in the elimination of the lag period which preceded the oxidation of protocatechuic acid, thus linking the metabolism of the compounds in a common pathway. Although it was not demonstrated by isolation from cultures on vanillin or vanillic acid that protocatechuic acid was an intermediate in their metabolism, in previous experiments with Aspergillus niger (Henderson, 1960) an indication of its production from vanillic acid was obtained. Also, vanillic acid is known to induce the synthesis of protocatechuic acid oxidase in Neurospora crassa (Gross \& Tatum, 1955). These authors found, however, that vanillic acid was not metabolized by their organism, in contrast to the fungi studied in the present work which not only oxidized it but could grow on it as sole source of carbon.

Experiments with crude cell-free extracts, in which $\beta$-ketoadipic acid formation was used to indicate protocatechuic acid oxidase activity, confirmed the above results. They can be summarized as follows:

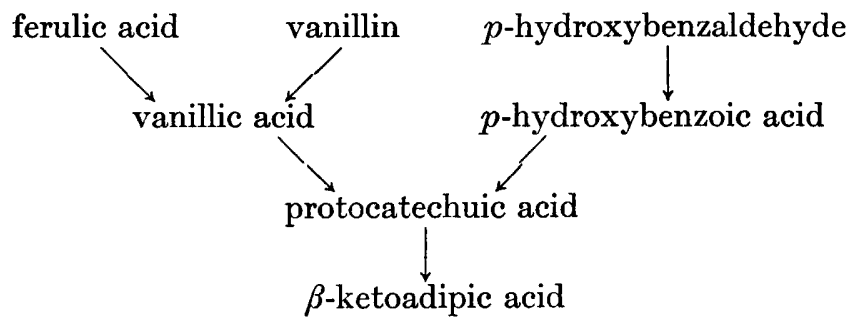

$o$-Hydroxybenzoic acid is frequently metabolized through catechol (Walker \& Evans, 1952; Henderson, 1960) which is further metabolized to yield cis-cis-muconic 
acid (Stanier \& Hayaishi, 1951) and $\beta$-ketoadipic acid (Evans \& Smith, 1951). The results obtained with $P$ ullularia pullulans indicated that it follows the $o$-hydroxybenzoic acid $\rightarrow$ catechol $\rightarrow$ cis-cis-muconic acid $\rightarrow \beta$-ketoadipic acid pathway. The course of metabolism of syringic acid was not elucidated. Protocatechuic acid oxidase activity in organisms which had been exposed to syringic acid was very low indeed, indicating that protocatechuic acid is not produced during metabolism of syringic acid. In being stimulated by $\mathrm{FeSO}_{4}$ this protocatechuic acid oxidase resembles those of Neurospora sp. (Ottey \& Tatum, 1956) and of Pseudomonas sp. (Dagley \& Patel, 1957) and not that of a soil pseudomonad studied by Ribbons \& Evans (1960) or that of liver (Stanier \& Ingraham, 1954). The occurrence of -SH groups in the enzyme was demonstrated by its inhibition by $p$-chloromercuribenzoate, which was annulled by glutathione. Protocatechuic acid oxidase of liver (Stanier \& Ingraham, 1954) was also inhibited by $p$-chloromercuribenzoate.

The author is indebted to Mr J. D. Russell for carrying out the spectrochemical analyses and to Professor R. P. Linstead for the gift of a sample of cis-cis-muconic acid. She wishes to thank Miss Dorothy Brebner for technical assistance and Dr D. M. Webley for his continuing interest in this work.

\section{REFERENCES}

Bachman, D. M., Dragoon, B. \& John, S. (1960). Reduction of salicylate to saligenin by Neurospora. Arch. Biochem. Biophys. 91, 326.

Bray, H. G., Thorpe, M. V. \& White, K. (1950). The fate of certain organic acids and amides in the rabbit. 10. The application of paper chromatography to metabolic studies of hydroxybenzoic acids and amides. Biochem. J. 46, 271.

Clark, W. M. (1928). The Determination of Hydrogen Ions, 3rd edn. London: Baillière, Tindall and Cox.

Dagley, S. \& Patel, M. D. (1957). Oxidation of $p$-cresol and related compounds by a Pseudomonas. Biochem. J. 66, 227.

Evans, W. C. \& Smith, B. S. W. (1951). The oxidation of aromatic compounds by soil bacteria. Biochem. J. 49, x.

Farmer, V. C., Henderson, M. E. K. \& Russell, J. D. (1959). Reduction of certain aromatic acids to aldehydes and alcohols by Polystictus versicolor. Biochim. biophys. Acta, 35, 202.

Gross, S. R. \& TATUM, E. L. (1955). Structural specificity of inducers of protocatechuic acid oxidase synthesis in Neurospora. Science, 122, 1141.

Henderson, M. E. K. \& FARMer, V. C. (1955). Utilization by soil fungi of $p$-hydroxybenzaldehyde, ferulic acid, syringaldehyde and vanillin. J. gen. Microbiol. 12, 37 .

Henderson, M. E. K. (1956). A study of the metabolism of phenolic compounds by soil fungi using spore suspensions. J. gen. Microbiol. 14, 684 .

Henderson, M. E. K. (1957). Metabolism of methoxylated aromatic compounds by soil fungi. J. gen. Microbiol. 16, 686.

Henderson, M. E. K. (1960). The influence of trace elements on the metabolism of aromatic compounds by soil fungi. J. gen. Microbiol. 23, 307.

Henderson, M. E. K. (1961). Isolation, identification and growth of some soil hyphomycetes and yeast-like fungi which utilize aromatic compounds related to lignin. 1 . J. gen. Microbiol. 26, 149.

McIlwain, H. (1948). Preparation of cell-free bacterial extracts with powdered alumina. J. gen. Microbiol. 2, 288.

Mitoma, C., Posner, H. S., Reitz, H. C. \& Udenfriend, S. (1956). Enzymatic hydroxylation of aromatic compounds. Arch. Biochem. and Biophys. 61, 431. 
Molinari, E. (1929). Biochemical dismutation : acetic fermentation. Biochem. Z. $216,187$.

Ottey, L. J. \& Tatum, E. L. (1956). Protocatechuic acid oxidase of Neurospora. J. biol. Chem. 223, 307.

Ribbons, D. W. \& Evans, W. C. (1960). Oxidative metabolism of phthalic acid by soil Pseudomonads. Biochem. J. 76, 310.

Rothera, A. C. H. (1908). Note on the sodium nitroprusside reaction for acetone. J. Physiol. 37, 491.

Sistrom, W. R. \& Stanier, R. Y. (1953). The mechanism of catechol oxidation by Mycobacterium butyricum. J. Bact. 66, 404.

Stanier, R. Y. \& Hayaishi, O. (1951). The bacterial oxidation of tryptophan : a study in comparative biochemistry. Science, 114, 326.

Stanier, R. Y. \& Ingraham, J. L. (1954). Protocatechuic acid oxidase. J. biol. Chem. 210, 798.

Walker, N. \& Evans, W. C. (1952). Pathways in the metabolism of monohydroxybenzoic acids by soil bacteria. Biochem. J. 52, xxiii.

Webley, D. M. \& DuFf, R. B. (1955). A convenient shaking machine for growing microorganisms. J. appl. Bact. 18, 122. 